\title{
Realization of an Economical $1 \times 3$ Fused-Taper-Twisted Polymer Optical Fiber Splitters for Small World Communication
}

\section{Mohd Syuhaimi Ab-Rahman, Hadi Guna* and Mohd Hazwan Harun}

Department of Electrical, Electronic \& System, Faculty of Engineering and Built Environment, Universiti Kebangsaan Malaysia, 43600 Bangi, Selangor Darul Ehsan, Malaysia.

*hadi_guna87@yahoo.com (Corresponding author)

Received on $29^{\text {th }}$ July 2009, accepted in revised form $19^{\text {th }}$ November 2009.

\begin{abstract}
Optical Fiber made by plastic or polymer, can be and is being used in various fields of application. Two of the main fields are the automotive and the home networking. polymer optical fiber (POF) here can be seen as one of the best solutions for small world communication, especially in home networking application. In this paper, optical $1 \times 3$ fused-taper-twisted POF splitters has been fabricated by a distinguished technique and proposed to be applied on small world communication application. There several systems available on the market, which can be split a coupled signal to be transmitted into some different channels, which are all afflicted with certain disadvantages. But all these solutions have one main constraint; very expensive for most of the applications as mentioned above. So the goal of this study is to fabricate an economical splitter for small world communication over POF. Characterization of the splitter was reported. Reach up until $668 \mathrm{~nm}$ wavelengths Light Emitting Diode (LED) has been injected into the splitter to determine and analyze the level of efficiency of the splitter. Final analysis shows that efficiency of splitter output able to reach up to $80 \%$. The device performance can be improved gradually through experience and practice. Main point here is the fabrication process is simple, easy and suitable to be used for household.
\end{abstract}

ABSTRAK Gentian optik yang diperbuat daripada bahan plastik atau polimer telahpun digunakan secara meluas pada beberapa aplikasi. Dua daripada bidang-bidang utama itu adalah automotif dan rangkaian rumah. POF disini dapat dilihat sebagai satu penyelesaian terbaik bagi komunikasi dunia kecil terutamanya bagi aplikasi rangkaian rumah. Dalam kajian ini, pencerai optik $1 \times 3$ terlakur-menirus-terpilin berasaskan POF telah direka menggunakan teknik yang khas dan dicadangkan akan digunapakai bagi aplikasi komunikasi dunia kecil. Ada beberapa sistem yang boleh didapati di pasaran, dimana ianya mampu menggandingkan isyarat optik yang akan diteruskan pada beberapa saluran-saluran yang berbeza, yang mana kebanyakan dari sistem tersebut menghadapi beberapa kekangan yang berbeza-beza. Namun dari pelbagai penyelesaian tersebut, kebanyakan sistem menghadapi satu kekangan yang utama iaitu ianya terlalu mahal untuk direka. Jadi, tujuan utama kajian ini ialah untuk mereka pencerai yang murah bagi kegunaan komunikasi dunia kecil berasaskan POF. Ujian pencirian juga dijalankan ke atas pencerai. Diod pemancar cahaya dengan panjang gelombang shingga mencapai $668 \mathrm{~nm}$ disuntik menerusi pencerai POF bagi tujuan pencirian pencerai optik untuk mengukur takat kecekapan terminal keluaran pencerai. Analisis akhir didapati bahawa terminal keluaran pencerai optik $1 \times 3$ berasaskan POF mampu mencapai $80 \%$ dari keseluruhan kuasa pencerai. Prestasi pencerai optik ini masih boleh dibaiki beransur-ansur melalui pengalaman dan amalan proses pembikinan. Yang paling penting ialah proses pembuatan peranti ini adalah ringkas, mudah dan sangat sesuai bagi kegunaan rumah.

(Keywords: Polymer optical fiber, POF, customer-made, fused-taper-twisted fiber, optical splitter, small world communication, home network.)

\section{INTRODUCTION}

The concept of "small world" networks has recently received much attention, although its origins stem from early work done some forty years ago on large, complex systems under assumptions that the underlying network stricture is random [2]. Many real world situations, including the World Wide Web [1], electric power grids [8], and the network of mathematicians with finite Erdos numbers [3] modelled as small world networks. The two main characteristics of small world networks are strong local clustering, and small diameter. Informally, clustering is the fraction of possible edges among neighbours of a node that are actually present, averaged over all nodes. Clustering, or locality, is a common property of many computations that require the exchange of information among processors, and 
clustering of communication is typical of many applications [2]. As computing power increased and real world network began to become available, empirical analysis extended to real-world networks with non-random characteristics.

Barabasi and Albert (1999) found that large complex networks posses' three properties, such as short average path length, high level of clustering, Powerlaw and exponential-degree distribution. Short average path length indicates that the distance between any two nodes on the network is short; they can be reached in a few numbers of hops along edges. Clustering occurs when nodes locate topologically close to each other in cliques.

For the purposes of practical use of small world communication systems, POF-based technology can be applied on it to connect some nodes. Figure 1 shows a connection number of users in small world communication system, for home network application.

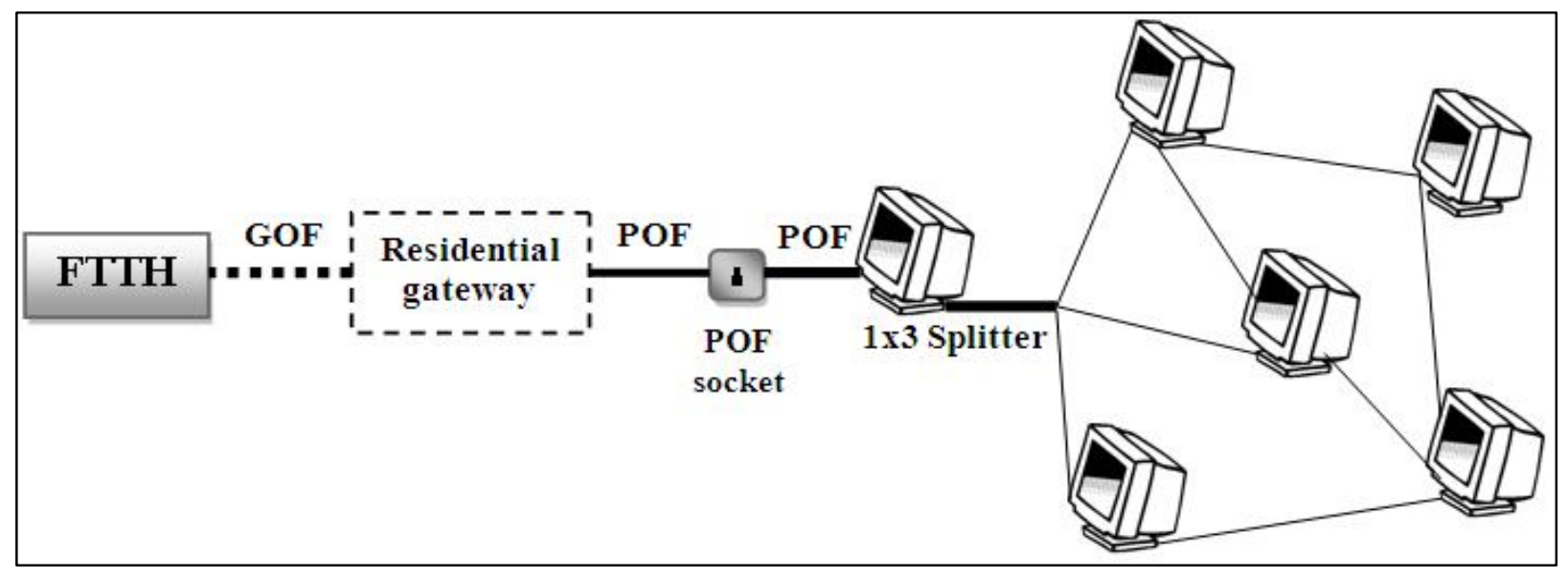

Figure 1. Small world communication application with POF-based technology using optical $1 \times 3$ POF splitter.

In the past few years, number of applications in communication and transportation based on optical fiber so rapidly developed as in the area of optical short-range communication. Demand POFs in application of communication was relatively high $[4,5,10,12]$, due to some characteristics strength of it, such as flexibility, easy to handle, relative low cost in coupling due to their large core diameter [7], heatproof, immune for noise (external electromagnet disruption), suitable for data communication for long distance up to 100 meter, high speed data transmission (400 Mbps for step index type and 1 Gbps for graded index type), higher bandwidth (exceed $4 \mathrm{GHz}$ ) and have losses below $25 \mathrm{~dB} / \mathrm{km}$ additional loss once it bent $[5,6,9,10]$.

In this paper, study for characteristics of POFs has been conducted for achieving desired design with some detail modification; besides it reliability to use them in small world communication systems has been investigated. In this case, the proposed fabrication design finally comes out with a real fused-taper-twisted POF splitter (see Figure 2).

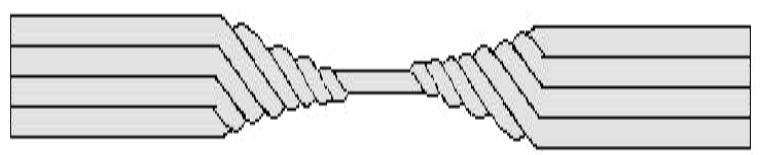

Figure 2. Fabrication of fused-taper-twisted POF
As a preliminary work on the investigation of prototype characterization, it also carried out to develop the design of end part of fused-taper-twisted POF splitter. In prototype characterization, some experiments were conducted to determine optical output power, POFs attenuation characteristics and power losses on the network.

\section{EXPERIMENTAL}

POF-based splitter is an optical device which ended by 3 POFs, while the other side ended by 1 POF. Furthermore, they both work bidirectional. However, they can work from the $1 \mathrm{POF}$ into $3 \mathrm{POF}$ or vice versa, for small world communication application we need to apply splitter function which operated from 1 POF separated into 3 POFs, and ensure the main signal from 1 POF can be separated into 4 signal efficiently.

\section{Material}

In development process of $1 \times 3$ splitter based on POF technology, multimode Step Index-POF (SI-POF) type made of polymethyl methacrylate (PMMA) 1 $\mathrm{mm}$ core size fully utilized in this paper, as PMMA is one of the most commonly used optical materials, Due to its intrinsic absorption loss mainly contributed by carbon-hydrogen stretching vibration in PMMA core POF [10]. 


\section{Prototype Development}

By overall, prototype development gives a priority in fabrication method due to expectation to generate an optical splitter with the specifications which meet research's requirement. Development process for the proposed technology can be seen in Figure 3.

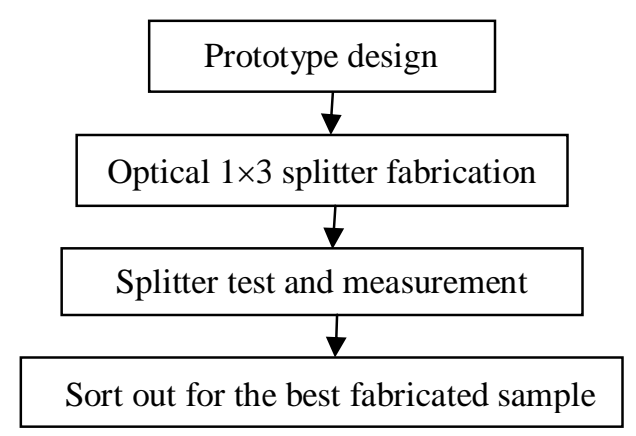

Figure 3. Flowchart for prototype development process.

\section{Prototype Design}

In this study, optical $1 \times 3$ splitter developed by the jointing of three PMMA POFs. Other specification for the design, the $1 \times 3$ splitter reach data transmission distance up to $40 \mathrm{~cm}$. Therefore, a POF cables (11 to $13 \mathrm{~cm}$ length) is required to be linked with each end part of three splitters (as an output) and also from the input side of the splitter (see Figure 4).

\section{Fabrication Method}

To fabricate the final product of optical $1 \times 3$ splitter, some stages has to be done, start from fiber fusion, bundle formation and finalized with cable jointing. Fabricated through fusion method by fuses and combine 3 POFs (in bundle form) and fabricate it ends part in a shape of fused-taper-twisted fibers (diameter $1 \mathrm{~mm}$ ). POFs will be twisted and pulled down while it is fused in a heat of flame. Heating process was done indirectly, while POFs covered by metal tube. Thus, heat was provided for POFs through metal tube indirectly (see Figure 5).

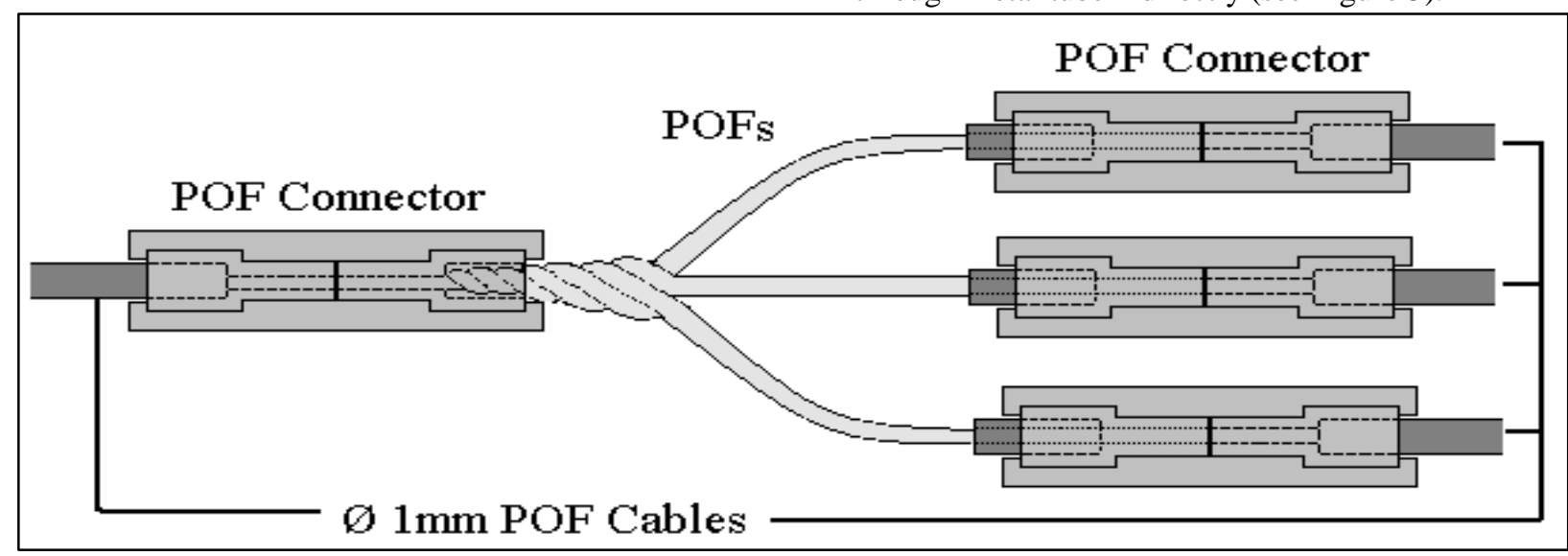

Figure 4. Optical $1 \times 3$ splitter design for small world communication application.

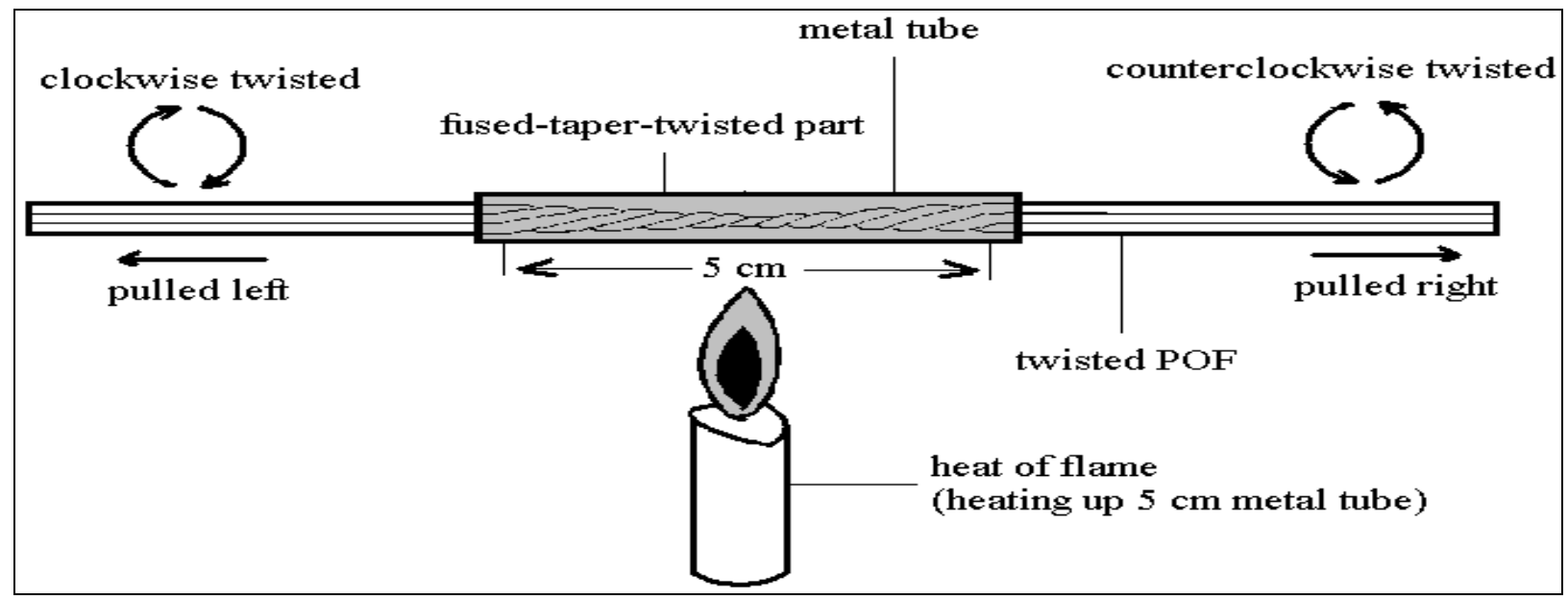

Figure 5. Fabrication method for fused-taper- twisted POFs. 
However, some of the POFs successfully fabricated before, some damaged sample still found from the fabrication aspects of it, e.g. imperfect shape or damaged cladding. A sample can be called ideal once its diameter uniformly fused - taper - twisted approaching $1 \mathrm{~mm}$. To confirm that samples unable to be used in characterization testing, these sample will be tested by red-LED injection. It is obtained that red-LED will not came out from the samples in a bad quality. Thus, the samples cannot be use in characterization testing, see Figure 6(a) and 6(b).

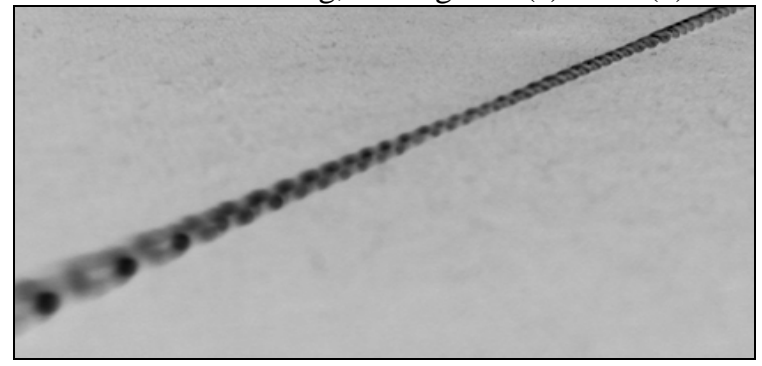

(a)

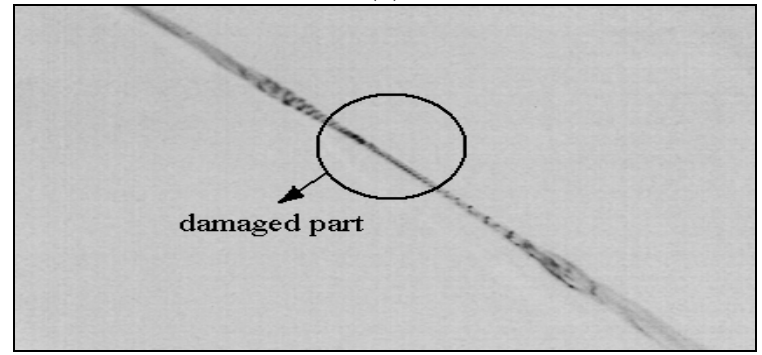

(b)

Figure 6. Final product of fused-taper-twisted POFs (a) meet the specification's requirement (b) with damaged formation.

To connect POF with user and to make it longer, it is suggested to use $1 \mathrm{~mm}$ POFs cable with a length around $11-13 \mathrm{~cm}$. Connection between $1 \times 3$ splitters and POFs cable joint by POFs connector ( $1 \mathrm{~mm}$ core diameter with jacket). POF connector contains two difference socket side, the one with a wide socket pit while other have a narrower. The end part of $1 \times 3$ taper-twisted POFs inserted into the socket with a wider slot and glued properly, so that the connection will be difficult to be pulled out. While the other slot side of connector inserted by POFs cable (see Figure 7).

After successfully linked the optical $1 \times 3$ splitter for 1POF side, fabrication method continued by connecting the other 3POFs side with the same way explained before (see Figure 8).

Optical power meter has been used to measure the optical power from POFs. Before the switch opened, it is obtained that $0.02 \mathrm{~mW}$ for it zero error exists on the meter. For the first stage for purpose of choosing the best sample to be used, POFs injected with $3 \mu \mathrm{W}$ input power to measure level of efficiencies of 10 fabricated twisted POFs samples. For the second stage, with the same procedure, $3 \mu \mathrm{W}$ powers has been injected into $\varnothing 1 \mathrm{~mm}$ POF cable (input side) to analyze it lost from both different sides. And the last stage required to be injected with $\mu \mathrm{W}$ into the whole system for a purpose of characterization procedure.

The best sample from fabrication process has been chosen. Ideally, once the input power starting injected into optical $1 \times 3$ splitter, the output and input will be the same. If we inject 1 end-POF with $3 \mathrm{~mW}$ optical power, than the other end side of 3 POFs could be reach $\sim 1 \mathrm{~mW}$ of output power for each POF.

In this study, characterization procedure needs to be carried out for each fabricated optical splitter. Each of developed splitter must be able to properly coupling an optical signal to generate 3 separated signals efficiently, with low power loss.

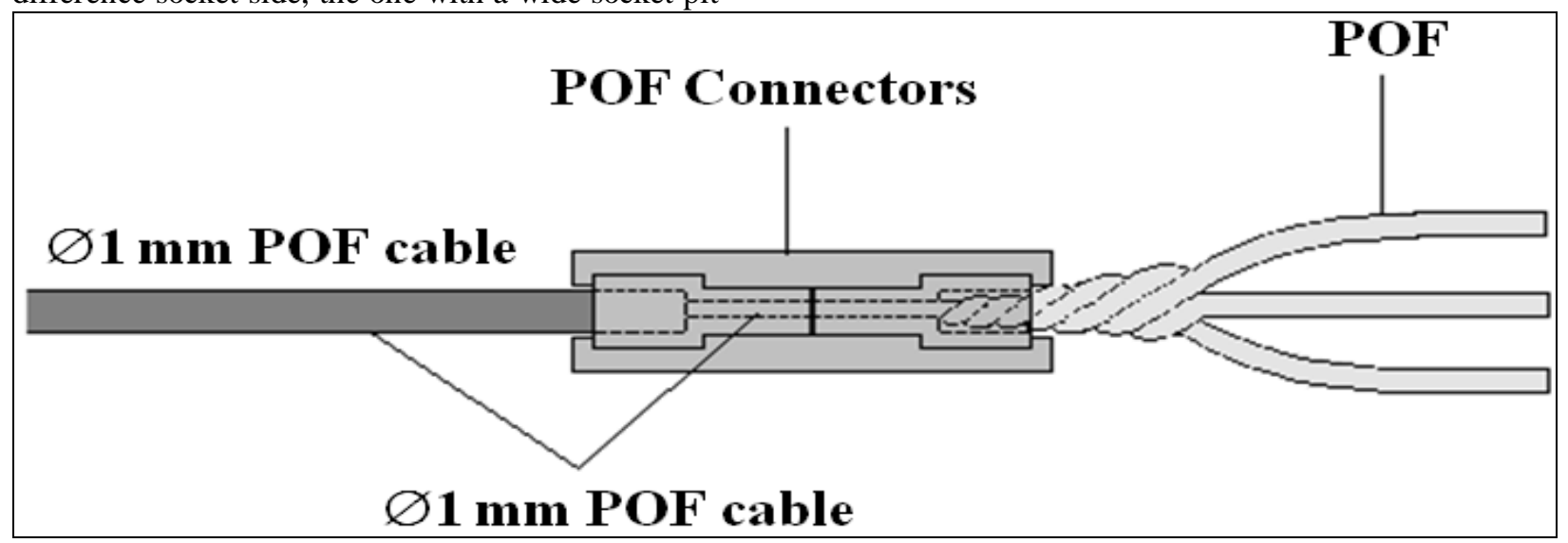

Figure 7. Connection between optical $1 \times 3$ splitter with $1 \mathrm{~mm}$ POF cable. 


\section{POF Connectors}

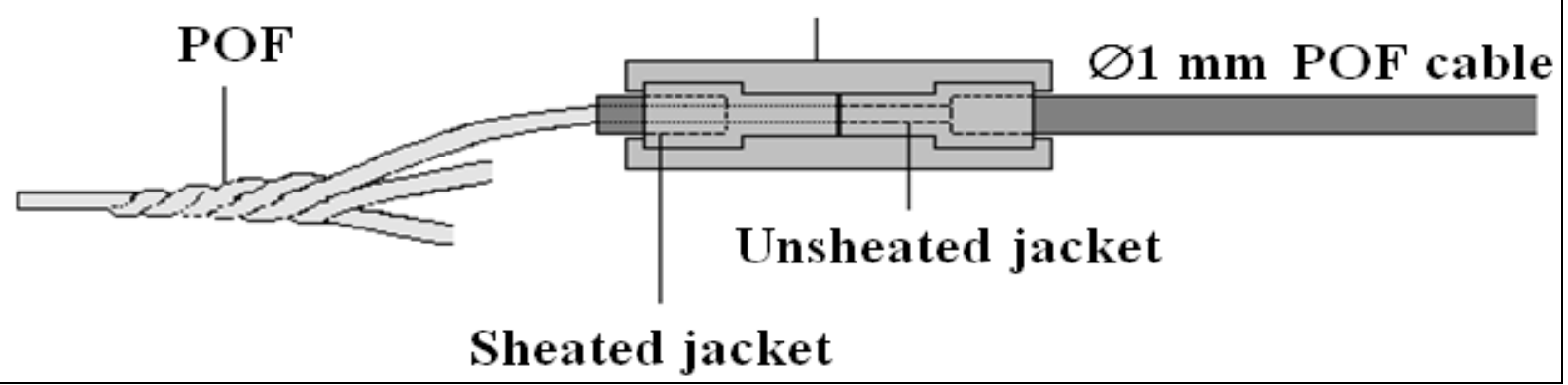

Figure 8. Connection between $1 \times 3$ splitter with $1 \mathrm{~mm}$ POF cable.

Furthermore, three characterization stages have been conducted. First, from some fabricated samples obtained, the best three samples have been chosen to be fully utilized in the research. Second stage is to choose the best sample continued with measurement of both side of twisted POF itself, include its power, lost and efficiencies. And the last stage, once the all three side of POF have been linked with $\varnothing 1 \mathrm{~mm}$ POF cable by connecter, measurement could be carried out to the entire system come with the $\varnothing 1$ mm POF cables (see Figure 9).

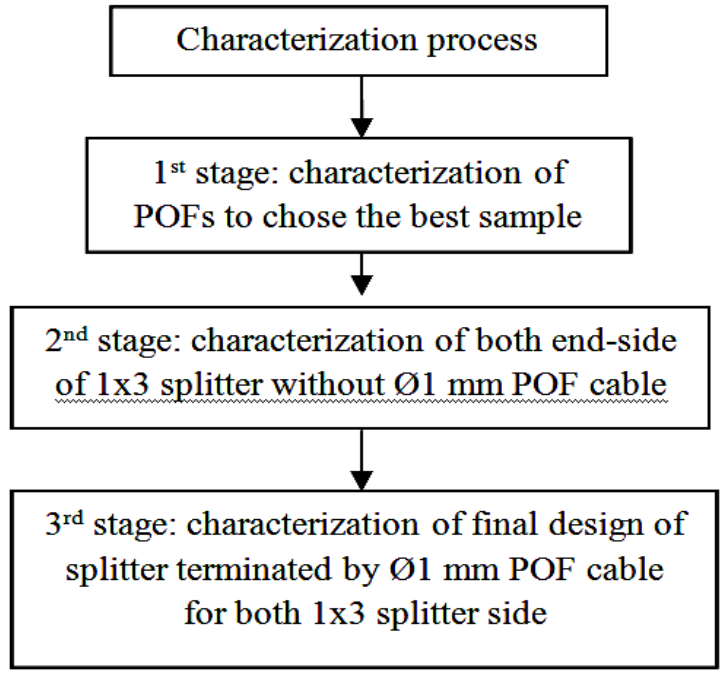

Figure 9. Characterization process flowchart.

Optical power meter has been used to measure the optical power from POFs. Before the switch opened, it is obtained that $0.02 \mathrm{~mW}$ for it zero error exists on the meter. For the first stage for purpose of choosing the best sample to be used, POFs injected with $3 \mu \mathrm{W}$ input power to measure level of efficiencies of 10 fabricated twisted POFs samples. For the second stage, with the same procedure, $3 \mu \mathrm{W}$ powers has been injected into $\varnothing 1 \mathrm{~mm}$ POF cable (input side) to analyze it lost from both different sides. And the last stage required to be injected with $\mu \mathrm{W}$ into the whole system for a purpose of characterization procedure.
The best sample from fabrication process has been chosen. Once the input power starting injected into optical $1 \times 3$ splitter, the output and input will be the same. If we inject 1 end-POF with $3 \mathrm{~mW}$ optical power, than the other end side of 3 POFs could be reach $\sim 1 \mathrm{~mW}$ of output power for each POF.

\section{RESULTS AND DISCUSSIONS}

The analysis of the prototype characterization was carried out, especially for it efficiency percentage of each POFs for all 3 stages in characterization process. So, the comparison for the all power efficiency of optical $1 \times 3$ splitter based on POFs has been observed, which the 1 end-POF act as an input and the other side which consist of 3 POFs stated as an output.

Some samples of POFs have been fabricated, red LED with $650 \mathrm{~nm}$ wavelength with $3 \mu \mathrm{W}$ input power, have been fully utilized to measure the efficiencies of all fabricated samples. Ten of the fabricated samples have been measured, it power output (see Figure 10). It is clear that, the best sample obtained is sample B, although the power output not separated equally from all three POFs of sample B.

From the observation above, the power efficiency of each output shows a different value. It is true; because error could be happened on it either while fabrication process or characterization test stages imposed on them. Irregularities of controlled heat while heating process exposed on the POFs become one of the major problem, due to it lower melting point makes core structure of POF could be more sensitive on heating process. Once it is damaged, it is hard to let a light pass through the core, or even not pass at all. 

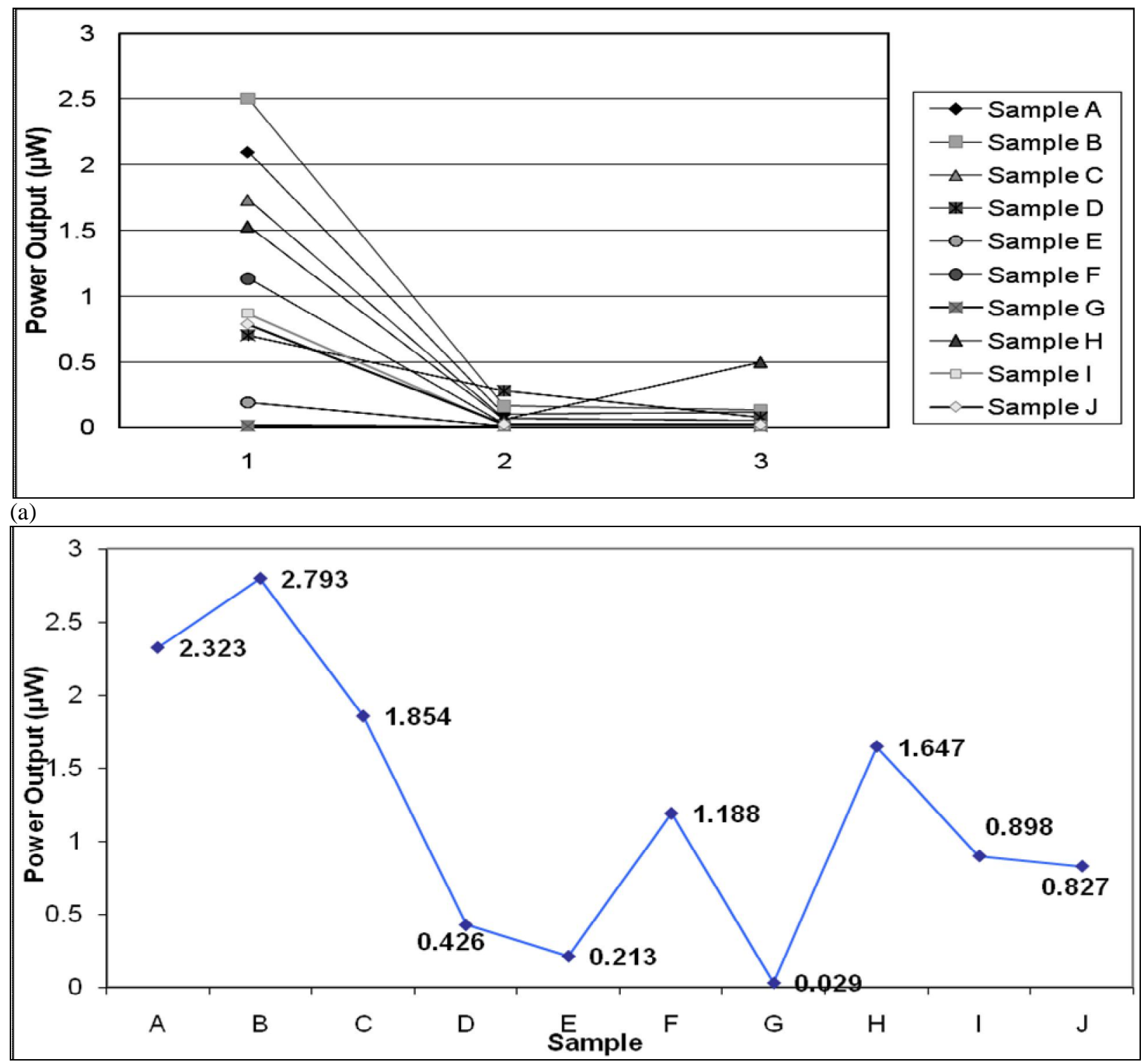

(b)

Figure 10. The output power measured (a) at three output port for ten units of splitter and (b) percentage of power efficiency.

From the observation above, the power efficiency of each output shows a different value. It is true; because error could be happened on it either while fabrication process or characterization test stages imposed on them. Irregularities of controlled heat while heating process exposed on the POFs become one of the major problem, due to it lower melting point makes core structure of POF could be more sensitive on heating process. Once it is damaged, it is hard to let a light pass through the core, or even not pass at all.

After the best samples have been chosen, the measurement of end-to-end efficiency of sample B need to be conducted to choose the best side of the sample before it connected to $\emptyset 1 \mathrm{~mm}$ POF cable using POF connector.

The procedure for this characterization is red LED was injected into the all three input of the POFs and measure for the three outputs of the other side of POFs, and vice versa. In here, both sides of samples $\mathrm{A}, \mathrm{B}$ and $\mathrm{C}$ have been observed to compare the two side of it (see Figure11). 


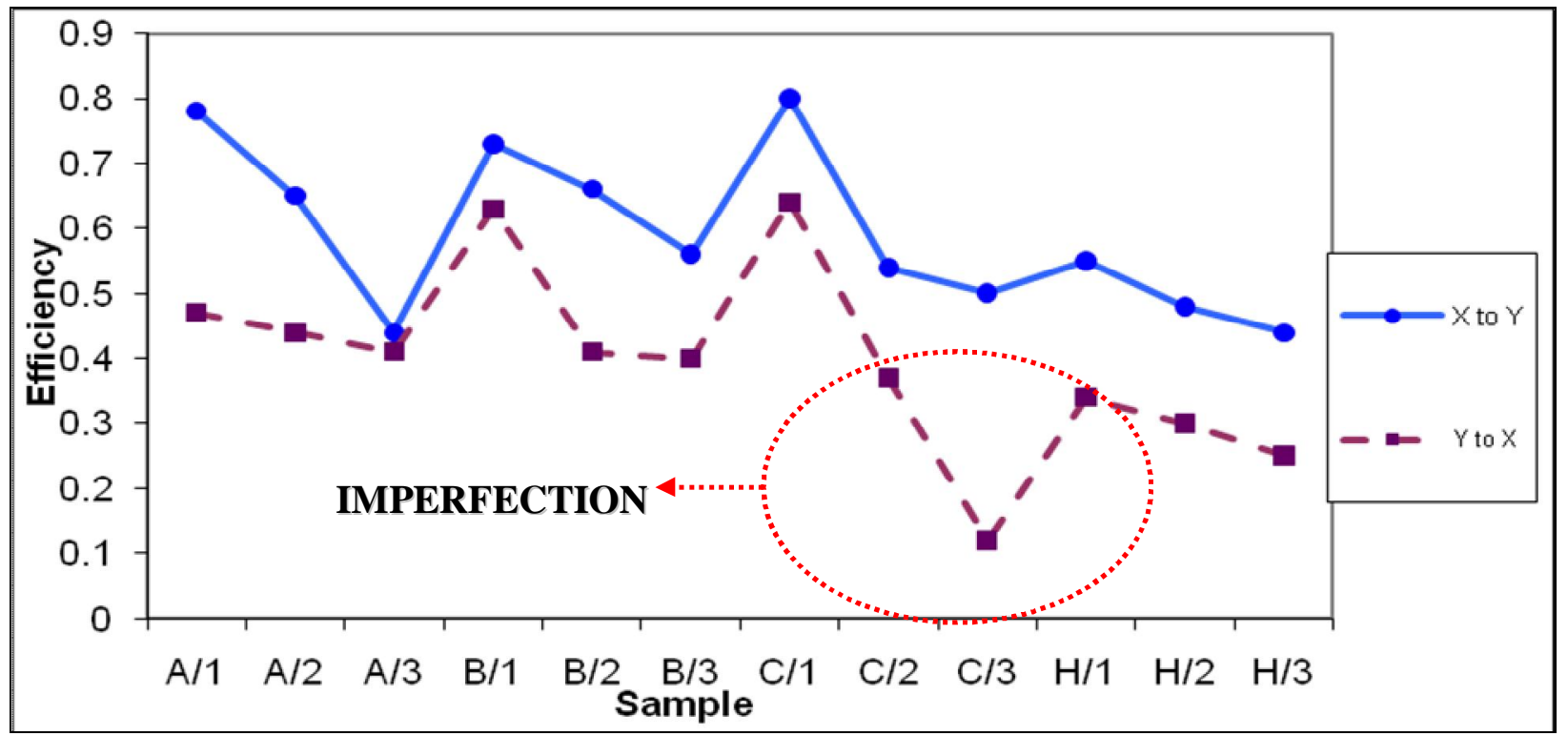

Figure 11. The efficiency calculated for three $3 \times 1 \mathrm{POF}$ optical splitter represent by $\mathrm{A}, \mathrm{B}, \mathrm{C}$ and $\mathrm{H}$ at different testing direction.

From the observation showed some imperfection of the shape of POFs if it is seen from the different side. The deviation power efficiency of the different side POFs measurement approximately reaches $30 \%$. From this characterization, the right side of $3 \mathrm{POFs}$ have been chosen to be used on the next stage of splitters development, due to it high efficiency.

The research continued by connecting the POFs with the $\varnothing 1 \mathrm{~mm}$ POF cable from both inputs and outputs side of the splitter, than measurement also conducted for the purpose of analysis whether the POF connector gave some impact on power efficiency of the splitter while it transmits the power, and the result can be seen in Figure 12.

Figure 11 we can see the average of three output (sample A, B and C) nearly same, but once the POF connector linked with the jointing between POFs and $\emptyset 1 \mathrm{~mm}$ POF it is clearly shown that the efficiency of sample B significantly drop to $7 \%$ of it efficiency, while for sample $\mathrm{A}$ and $\mathrm{C}$ have almost the same efficiency of output power. It is proven that POF connector also plays a main role on the efficiency of the splitter.

Comparison between handmade and commercial splitter have been made, and the result as illustrated in Figure 13. At this point we would now like to define the term "connector attenuation". Strictly speaking, a connector does not have any defined losses, only a fiber-to fiber connection has losses. The light losses are caused by: inexact alignment of the fibers to each other, whereby the parameters of the fiber, the connector and the coupling could be responsible, the fiber parameters not being adapted to each other, e.g. different numerical apertures, and direct losses at the fiber end face through reflection, scattering and absorption [5].

Many factors can affect the efficiency level of splitter, other than imperfect shape, fabrication failure, and improper of jointing process, the presence of surrounding light, could be one of the factor cause an error on optical power meter, although have a low intensity they gave a high sensitivity on it. Optical power meter able to reach nanowatt external power, hence, disruption from external source of light ensured to be avoided during the power measurement conducted.

\section{CONCLUSIONS}

There are many technology e.g. Dutch-sponsored researcher Christos Tsekrekos has investigated how a small network for at home or in a company can function optimally. His technique transmits each TV, telephone and Internet signal via a separate group of light rays through the optical fiber cable. Such a technology has not yet been marketed. Yet in the ideal situation it could be applied in a glass or polymer fiber, has the potential of being cheap, and transmits all information without disruption. Existing systems for small networks at home or in a company make use of multimode glass fibers or multimode polymer optical fibers (POF). 


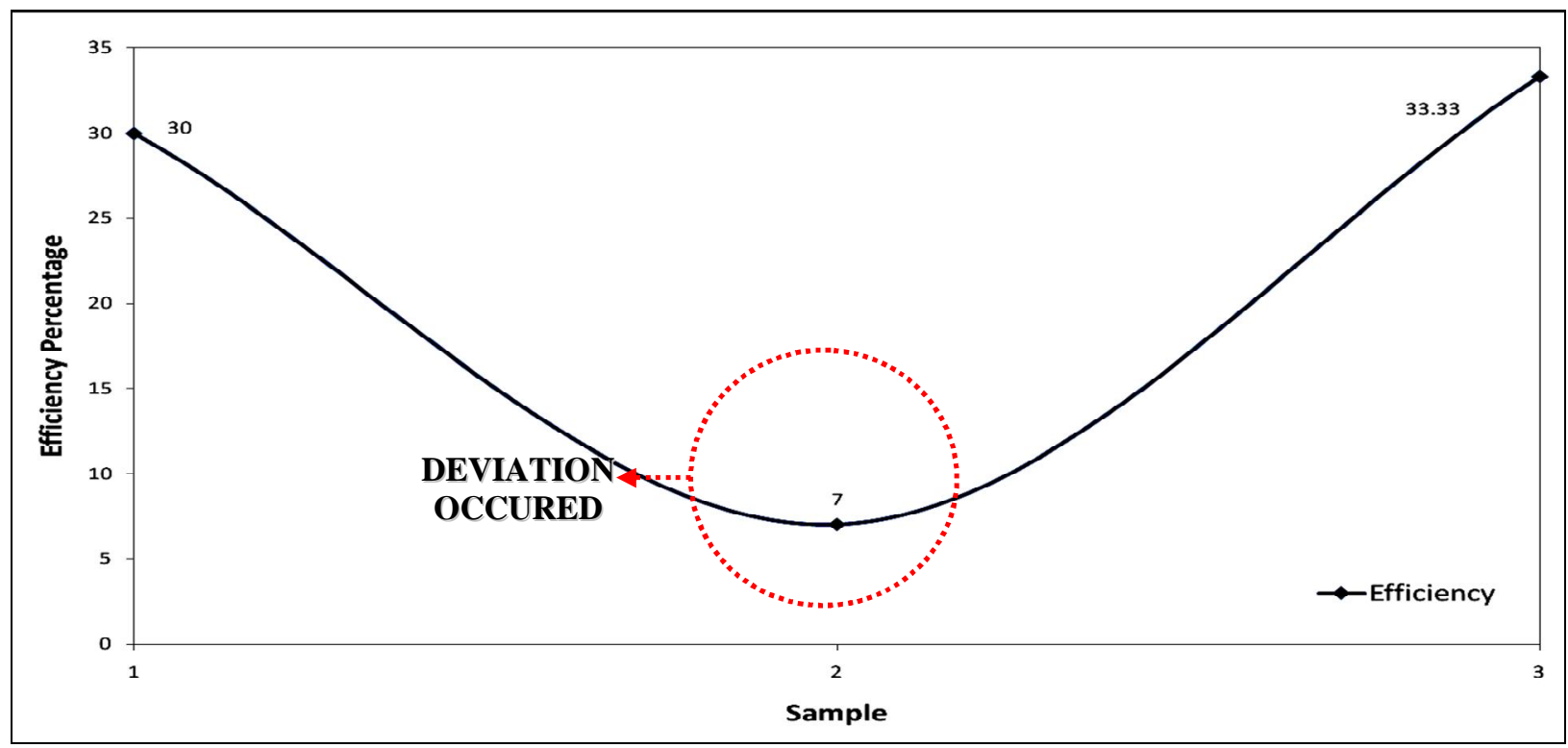

Figure 12. Efficiency deviation occurred right after the POF connecter jointed with splitters and $\emptyset 1 \mathrm{~mm}$ POF cables

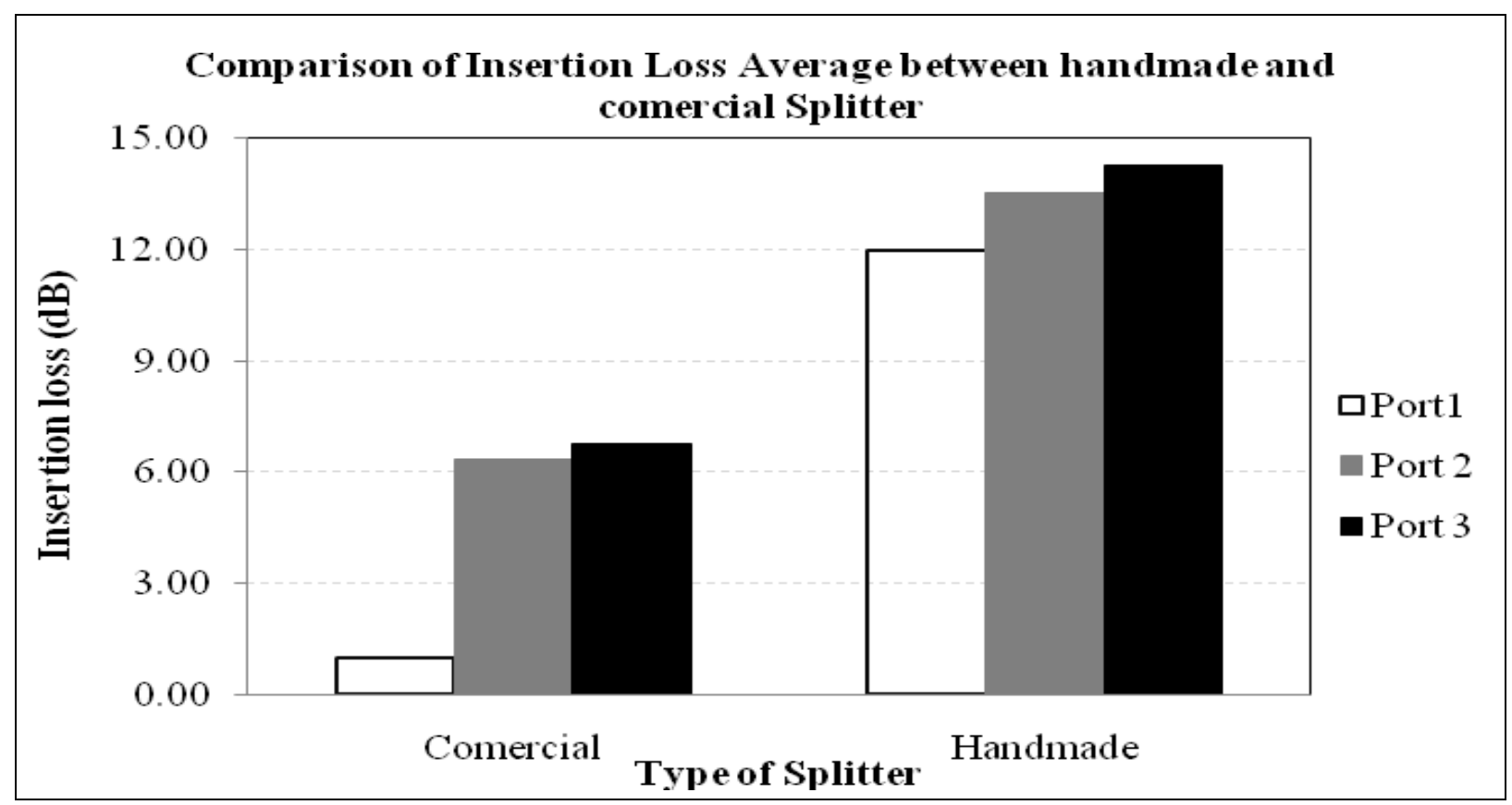

Figure 13. Performance comparison of handmade fused-taper-twisted and commercial splitter in term of their insertion loss. The deviation nearly reach $10 \mathrm{~dB}$ between handmade and the commercial splitter.

The latter are relatively thick cables (about $1 \mathrm{~mm}$ thick, thus thicker than the glass fiber which is 0.125 $\mu \mathrm{m}$ thick). Multimode fiber cables can conduct many light rays and can operate free of disruption and with a greater bandwidth than a wireless connection.

However, due to a slight variation in the speed of the light rays through the multimode fiber, a signal transmitted by all of these rays becomes spread out.
Consequently, the signals become broader and therefore fewer signals fit in the fiber, limiting the transmission capacity. These demands grow almost daily. Hence new ways of splitting methods must be found to satisfy all application demands, especially related to small world communication.

In conclusion, a perform technique has been used to fabricate optical $1 \times 3$ splitter with based on POFs 
technology. Multimode SI-POF type with $1 \mathrm{~mm}$ core size fully utilized for the base material of the splitter. Some procedures, such as fabrication and characterization stages have been carried out to develop the splitter.

Red LED reach up till $668 \mathrm{~nm}$ wavelength, has been injected into the splitter for the purpose of characterization testing to analyze the level of power efficiency of the splitter. Final analysis shows that efficiency of splitter output able to reach up to $80 \%$.

The device performance can be improved gradually through experience and practice. Main point here is, the fabrication process is simple, easy and suitable to be used for household. Moreover, the users can determine the size of the fabricated device themselves either $1 \times 2,1 \times 3,1 \times 4,1 \times 8$ and more, according to the twisting technique and cylinder tube size.

The POF-based optical $1 \times 3$ splitter have been suggested to be applied in home networking and small world communication to avoid the bottleneck occurs between ONU and electronic appliances, resulting increase the speedy of data communication. Home network deals with transmission triple play signals by means of data, voice and video.

\section{ACKNOWLEDGMENTS}

The research activity had been conducted in Photonic Technology Laboratory, Institute of Micro Engineering and Nanoelectronics (IMEN), Universiti Kebangsaan Malaysia (UKM). The authors would like to thank Prof. Dr. Sahbudin Shaari for his invaluable help in model development and simulation prior to this work. This work was supported by the Malaysian Ministry of Science, Technology and Innovation (MOSTI) under Research University Grant (Geran Universiti Penyelidikan, GUP) UKM-GUP-TMK-07-02-108. This research was rewarded with the Gold Medal of Invention, Innovation and Technology Exhibition 2009, Kuala Lumpur and become one of the finalists in Anugerah Inovasi Negara 2009.

\section{REFERENCES}

1. Barabasi, A.L., and Albert, R., "Emergence of scaling in random networks", Science, 286, pp. 509-12, 1999.

2. Bermond, J.C., Comellas, F., and Hsu, D.F., "Distributed loop computer networks: A survey", J. Parallel Distribute. Computer, 24, pp. 2-10, 1995.
3. Castro, R., and Grossman, J.W., "Famous trails to Paul Erdoos", Math Intelligencer, 3, pp. 5163, 1999.

4. Grzemba, A., MOST: The Automotive Multimedia Network, Franzis, Kevelaer, Germany, 2008.

5. Kuzyk, M.G., Polymer Fiber Optics: Materials, Physics, and Applications, Taylor \& Francis Group, Boca Raton, USA, 2007.

6. Liu, H.Y., Liu, H.B., Peng, G.D. and Chu, P.L., "Polymer optical fibre systems and devices", Opt. Commun, 220, pp. 337-343, 1999.

7. Nihei, E., and Shimizu, S., "Determination of the refractive index profile of polymer optical fiber preform by the transverse ray tracing method", Opt. Commun, 275, pp. 14-21, 2007.

8. Watts, D.J., and Strogatz, H., "Collective dynamics of 'small-world' networks", Nature, 393, pp. 440-42, 1998.

9. $\mathrm{Xu}, \mathrm{X}$., "Properties of $\mathrm{Nd} 3+$-doped polymer optical fiber amplifiers", Opt. Commun, 225, pp. 55-59, 2003.

10. Yu, R.J., Zhang, B., Chen, M., Huo, L., Tian, Z., and Bai, X., "A new solution of reducing polymer optical fiber losses", Opt. Commun. 266, pp. 536-40, 2006.

11. Zhang, Y., Pickrell, G.R., Qi, B., Jazi, A.S., and Wang, A., "Single-crystal Sapphire Based Optical Polarimetric Sensor for High Temperature Measurement", Sensors, 6, pp. 823-34, 2006.

12. Zieamann, O., Krauser, J., Zamzow, P.E., and Daum, W., POF Handbook: Optical Short Range Transmission Systems, 2nd, Springer, Berlin, Germany, 2008. 
Malaysian Journal of Science 28 (3): 289 - 297 (2009) 